\title{
Local Injection of a Selective Endothelin-B Receptor Agonist Inhibits Endothelin-1-Induced Pain-Like Behavior and Excitation of Nociceptors in a Naloxone-Sensitive Manner
}

\author{
Alla Khodorova,, ${ }^{1,2}$ Moin U. Fareed, ${ }^{1 *}$ Alexander Gokin,, ${ }^{1,2}$ Gary R. Strichartz,, ${ }^{1,2,3}$ and Gudarz Davar ${ }^{1}$ \\ ${ }^{1}$ Molecular Neurobiology of Pain, ${ }^{2}$ Sensory Neurophysiology Laboratories of the Pain Research Center, Department of \\ Anesthesiology, Perioperative and Pain Medicine, Brigham and Women's Hospital, and 'Department of Biological \\ Chemistry and Molecular Pharmacology, Harvard Medical School, Boston, Massachusetts 02115
}

\begin{abstract}
We showed previously that subcutaneous injection of the injury-associated peptide mediator endothelin-1 (ET-1) into the rat plantar hindpaw produces pain behavior and selective excitation of nociceptors, both through activation of $\mathrm{ET}_{\mathrm{A}}$ receptors likely on nociceptive terminals. The potential role of $\mathrm{ET}_{\mathrm{B}}$ receptor activation in these actions of ET-1-has not been examined. Therefore, in these experiments, we studied the effect of blocking or activating $\mathrm{ET}_{\mathrm{B}}$ receptors on $\mathrm{ET}$-1-induced hindpaw flinching and excitation of nociceptors in rats. An $E T_{B}$ receptor-selective antagonist, $B Q-788(3 \mathrm{~mm})$, coinjected with ET-1 $(200 \mu \mathrm{M})$ reduced the time-to-peak of flinching and significantly enhanced the average maximal flinch frequency (MFF). In contrast, coinjection of an $\mathrm{ET}_{\mathrm{B}}$ receptor selective agonist, IRL-1620 (100 or $200 \mu \mathrm{M})$, with ET-1 reduced the average MFF and the average total number of flinches. Interestingly, this unexpected inhibitory effect of IRL-1620 was prevented by the
\end{abstract}

nonselective opioid receptor antagonist naloxone (2.75 mm). To confirm these inhibitory actions, we studied the effects of IRL1620 on ET-1-induced spike responses in single, physiologically characterized nociceptive C-fibers. IRL-1620 suppressed spike responses to ET-1 in all $(n=12)$ C-units, with mean and maximum response frequencies of $0.08 \pm 0.02$ and $1.5 \pm 0.4$ impulses/sec versus $0.32 \pm 0.07$ and $4.17 \pm 0.17 \mathrm{impulses} / \mathrm{sec}$ for ET-1 alone. In additional support of the behavioral results, coinjection of naloxone $(2.75 \mathrm{~mm})$ completely prevented this inhibitory action of IRL-1620. These results establish that $E T_{B}$ receptor activation inhibits $E$ T-1-induced pain behavior and nociception in a naloxone-sensitive manner and point to a previously unrecognized dual modulation of acute nociceptive signaling by $\mathrm{ET}_{\mathrm{A}}$ and $\mathrm{ET}_{\mathrm{B}}$ receptors in cutaneous tissues.

Key words: nociception; analgesia; G-protein; endothelin-1; opioid; potassium channel
Endothelin-1 (ET-1) is a potent, endogenous vasoactive peptide (Hickey at al., 1985; Yanagisawa et al., 1988) whose effects are mediated by two distinct G-protein-coupled receptors, the endothelin- $\mathrm{A}\left(\mathrm{ET}_{\mathrm{A}}\right)$ and the endothelin-B $\left(\mathrm{ET}_{\mathrm{B}}\right)$ receptor, which usually mediate vasoconstriction and vasodilatation, respectively (Rubanyi and Polokoff, 1994). Interestingly, ET-1 has a role in pain signaling in animals and humans (Hammerman et al., 1997; Davar et al., 1998; De-Melo et al., 1998; Graido-Gonzalez et al., 1998; Jarvis et al., 2000). For example, in rodents, intraperitoneal administration of ET-1 produces an abdominal writhing response that is $\mathrm{ET}_{\mathrm{A}}$ receptor mediated and that may be behavioral evidence of acute pain (Raffa et al., 1996a,b). Intra-articular administration of ET-1 also has been shown recently to induce pain in rodents that is $\mathrm{ET}_{\mathrm{A}}$ receptor mediated, and ET-1 is known to potentiate pain states in several animal models of acute chemicalor inflammation-induced pain (Ferreira et al., 1989; Piovezan et al., 1997, 1998, 2000). In humans, the intra-arterial administration of ET-1 is reported to induce severe pain that is associated with prolonged touch-evoked allodynia in the injected limb (Dahlof et

\footnotetext{
Received Feb. 28, 2002; revised June 10, 2002; accepted June 13, 2002.

This work was supported by United States Public Health Service Grant CA 80153. We acknowledge the technical assistance of Jamie Bell and consultative help from Dr. Guy Hans.

*A.K., M.U.F., and A.G. contributed equally to this work.

Correspondence should be addressed to Dr. Gudarz Davar, Molecular Neurobiology of Pain Laboratory, Department of Anesthesiology, Perioperative and Pain Medicine, Brigham and Women's Hospital, 75 Francis Street, Boston, MA 02115. E-mail: gdavar@zeus.bwh.harvard.edu.

Copyright (C) 2002 Society for Neuroscience $\quad 0270-6474 / 02 / 227788-09 \$ 15.00 / 0$
}

al., 1990), and, more recently, Carducci et al. (1998) have reported that antagonists of the endothelin-A receptor can reduce pain in patients with metastatic prostate cancer. Consistent with a role in cutaneous injury, ET- 1 is also oversecreted after skin damage (Ahn et al., 1998) in which it might contribute to both local inflammation (Griswold et al., 1999) and pain.

Consistent with this evidence of ET-1-induced pain in animals and humans, we described recently $\mathrm{ET}_{\mathrm{A}}$ receptor-dependent flinching behavior and selective excitation of nociceptors after subcutaneous injection of ET-1 into the rat plantar hindpaw (Gokin et al., 2001). At a cellular level, we demonstrated ET $_{\mathrm{A}}$ receptor-mediated excitation of nociceptor-like sensory neurons (ND7 cells) and enhancements of tetrodotoxin-resistant sodium currents in acutely isolated rat dorsal root ganglion neurons (Chen et al., 2000; Zhou et al., 2001, 2002). These results, together with anatomic evidence of $\mathrm{ET}_{\mathrm{A}}$ (but not $\mathrm{ET}_{\mathrm{B}}$ ) receptors on small-diameter DRG neurons and their axons (Pomonis et al., 2001), further strengthen the potential importance of ET-1 (and $\mathrm{ET}_{\mathrm{A}}$ receptors) in the pathogenesis of pain.

Whereas a role for $\mathrm{ET}_{\mathrm{A}}$ receptors in ET-1-induced pain has been established, the importance of $\mathrm{ET}_{\mathrm{B}}$ receptors for this pain is not known. Although antihyperalgesic effects of $\mathrm{ET}_{\mathrm{B}}$ receptor activation have been described in some models of exogenous ET-1 delivery (Piovezan et al., 2000), the mechanism of this effect has not been determined. Furthermore, despite evidence to support a role for the $\mathrm{ET}_{\mathrm{B}}$ receptor in cutaneous inflammation (Griswold et al., 1999), the role of the $\mathrm{ET}_{\mathrm{B}}$ receptor in acute pain produced by ET-1 administration remains unknown. Therefore, 
in these experiments, we examined the effects of either a locally administered $\mathrm{ET}_{\mathrm{B}}$ receptor antagonist or an $\mathrm{ET}_{\mathrm{B}}$ receptor agonist on hindpaw flinching and excitation of nociceptors induced by the acute subcutaneous application of ET-1. The potential role of opioid receptors in $\mathrm{ET}_{\mathrm{B}}$ receptor-mediated inhibition of ET-1induced flinching and nociceptive firing that we observed during the course of these experiments was also examined.

\section{MATERIALS AND METHODS}

General. Experiments were performed on 122 adult (175-225 gm) male Sprague Dawley rats (Harlan Sprague Dawley, Indianapolis, IN). All procedures were approved by the Standing Committee on Animals at Harvard Medical School. Animals were treated and cared for according to the ethical standards and guidelines for investigators of experimental pain in animals prescribed by the Committee for Research and Ethical Issues of the International Association for the Study of Pain (Zimmermann, 1983). All rats were housed in a viral antibody-free facility (three per cage) on a $12 \mathrm{hr}$ light/dark cycle with food and water available ad libitum. Before beginning experiments, animals were handled for 1-2 d and were thereby acclimated to both the testing environment and the experimenters.

Drugs. All drugs were diluted in PBS (Invitrogen, Rockville, MD), $\mathrm{pH}$ 7.4, and kept on ice during experiments. Synthetic ET-1 (98\% pure peptide content), the $\mathrm{ET}_{\mathrm{B}}$ receptor-selective antagonist BQ-788 ( $N$-cis2,6-dimethylpiperidinocarbonyl-L- $\gamma$-methylleucyl-D-1-methoxycarbonyltrptophanyl-D-Nle) (reported $\mathrm{IC}_{50}$ of $1.2 \mathrm{nM}$ at the $\mathrm{ET}_{\mathrm{B}}$ receptor and 1.3 $\mu \mathrm{M}$ at the $\mathrm{ET}_{\mathrm{A}}$ receptor) (Ishikawa et al., 1992), and the $\mathrm{ET}_{\mathrm{B}}$ receptorselective agonist IRL-1620 (Suc-Asp-Glu-Glu-Ala-Val-Tyr-Phe-AlaHis-Leu-Asp-lle-lle-Trp) (reported $K_{\mathrm{I}}$ of $16 \mathrm{pM}$ at the $\mathrm{ET}_{\mathrm{B}}$ receptor and $1.9 \mu \mathrm{M}$ at the $\mathrm{ET}_{\mathrm{A}}$ receptor) (Takai et al., 1992) were supplied by American Peptides (Sunnyvale, CA). The concentration of ET-1 used $(200 \mu \mathrm{M})$ gives less than a saturating response for flinching behavior, as described by Fareed et al. (2000). Therefore, we assume that we are providing an effective concentration of ET-1 to target receptors that is less than four times the $K_{\mathrm{D}}$ ( $80 \%$ occupancy), where the $K_{\mathrm{D}}$ for both the $\mathrm{ET}_{\mathrm{A}}$ and $\mathrm{ET}_{\mathrm{B}}$ receptors are in the high picomolar to low nanomolar range (Rubanyi and Polokoff, 1994). BQ-788 was used at concentrations well in excess of the $K_{\mathrm{I}}(\sim 100 \mathrm{nM})$ (Webber et al., 1998) to ensure complete blockade of the $\mathrm{ET}_{\mathrm{B}}$ receptor. Naloxone was obtained from Sigma (St. Louis, MO) and dissolved in PBS. The dose of naloxone used for local injection was based on previously described reports of efficacy in rat models of cutaneous pain (Stein et al., 1990a; Eisenberg et al., 1996).

Injection procedures. For injections, naive rats were briefly anesthetized with the rapidly reversible inhalational anesthetic sevoflurane (3-4 min of inhalation). The method of ET-1 administration that we described previously (Gokin et al., 2001) was modified as follows to minimize the volume injected and to reduce the number of injections. Control and experimental subcutaneous injections were always performed as either a single $20 \mu \mathrm{l}$ injection (for the $4 \mathrm{nmol}$ dose of ET-1 alone) or as two sequential $10 \mu \mathrm{l}$ injections. The first injection always contained one of the following: vehicle (when examining the effects of ET-1 alone), an $\mathrm{ET}_{\mathrm{B}}$ receptor agonist or antagonist, or naloxone. The second injection contained ET- 1 mixed with one of these agents. Agonists, antagonists, and naloxone were always injected at the same concentration for both injections and were given in the first injection to optimize binding to the target. The first injection was made $40 \mathrm{sec}$ after the onset of limb cooling as described by Gokin et al. (2001). The hindlimb was cooled with a small amount of packed ice in a $15 \mathrm{ml}$ polypropylene centrifuge tube (Corning, Corning, NY) placed beneath the limb; a small amount of ice in a small $(\sim 25 \mathrm{ml})$ plastic bag was also placed on top of the hindlimb. The second injection was performed 1.5-2 min after the first injection. Both injections were delivered subcutaneously into the midplantar paw. After the first injection, the area was lightly outlined with a felt tip marker, and the second injection was made along the same needle track into the marked area, usually $\sim 1 \mathrm{~cm}$ distal to the heel.

Behavioral assessments. Behavioral assessments were performed as described previously (Davar et al., 1998), with animals freely moving on a flat surface that was enclosed by an inverted, large clear Plexiglas cage. Repetitive and spontaneous flinching of the ipsilateral hindpaw (rapid lifting of the entire hindlimb that begins with hip flexion and includes dorsiflexion of the toes) and the number of events and duration of biting or licking were counted beginning 5 min after ET-1 injection and continuing every $5 \mathrm{~min}$ for $75 \mathrm{~min}$ of observation. Blinding was performed in initial studies by providing experimenters with unlabeled tubes containing ET-1 or control solutions. However, the very clear and robust effect of ET-1 when compared with PBS made it difficult for the experimenters to remain blind. Similar results (effect readily discerned) were obtained when comparing ET-1 with BQ-788, IRL-1620, and naloxone, reducing the usefulness of blinding.

Neurophysiological experiments. Using methods we described previously in detail (Gokin et al., 2001), single-unit nerve activity was recorded from the right sciatic nerve before and after injection of ET-1, IRL-1620 together with ET-1, or IRL-1620 together with ET-1 and naloxone. Briefly, 12 adult male Sprague Dawley rats weighing 250-300 gm (Harlan Sprague Dawley) were initially anesthetized with intraperitoneal urethane $(1.3 \mathrm{gm} / \mathrm{kg} ;$ Sigma $)$ or sodium pentobarbital $(50-60$ $\mathrm{mg} / \mathrm{kg}$ ). The right jugular vein was cannulated to permit intravenous administration of additional doses of sodium pentobarbital to maintain general anesthesia, titrated to the absence of corneal reflexes, accelerated heart rate, and withdrawal reflexes to noxious stimuli. Heart rate was monitored with a Tektronix (Beaverton, OR) 498 EKG monitor. Tracheotomy was performed for artificial respiration. During recordings, rats were immobilized with pancuronium bromide $\left(1 \mathrm{mg} \cdot \mathrm{kg}^{-1} \cdot \mathrm{h}^{-1}\right.$, i.v.; Sigma) and artificially ventilated via a respirator (RSP1002; Kent Scientific, Torrington, $\mathrm{CT}$ ). End-tidal $\mathrm{CO}_{2}$ was continuously monitored with an end-tidal $\mathrm{CO}_{2}$ analyzer (IITC Life Science, Woodland Hills, CA) and maintained at $4-4.5 \%$. Core body temperature was monitored by a rectal thermometer and maintained at $36-37.5^{\circ} \mathrm{C}$ with a circulating water heating pad and heating lamps. At the end of an experiment, rats were killed with an overdose of sodium pentobarbital $(100-200 \mathrm{mg} / \mathrm{kg}$, i.v. $)$.

To record single-unit activity, a restricted skin incision was made over the posterior hindlimb, and the skin and muscle were opened to expose the middle and distal part of the sciatic nerve. Rats were then placed in a stereotaxic frame (David Kopf Instruments, Tujunga, CA) to immobilize the lower spine and pelvis. The skin at the incision was sewn to a metal ring to form a pool. The fascia and sheath overlying the sciatic nerve were carefully removed, and the nerve was placed on a platform and covered with warm mineral oil. Small nerve filaments, transected proximally, were teased gently from the sciatic under a dissecting microscope (Zeiss, Thornwood, NY). Isolated fine filaments were then wrapped around a silver wire recording electrode, which was connected to a high-impedance probe. One or two such electrodes were used for recording from one or two separate microfilaments. Reference electrodes were placed in the surrounding tissues.

The action potential of an isolated afferent fiber was amplified $1000 \times$, filtered with a bandwidth of 300-3000 Hz with a DAM8 amplifier (World Precision Instruments, Sarasota FL). Filtered signals were visualized on an oscilloscope (model 5301; Tektronix), with parallel audio monitoring, and recorded and stored on computer disc using the CED1401 Plus interface (Cambridge Electronics Design, Cambridge, UK) coupled to a Pentium processor-based personal computer. Signals were analyzed with Spike-3 software (Cambridge Electronics Design). Discharge frequency was counted by using spike shape discrimination (Spike-2; Cambridge Electronics Design), and a histogram was created for each fiber. The nerve activity is presented here as both native records and bin histograms.

To search for units, we used electrical stimulation of nerve fibers at a site between the recording site and the receptive field (RF) of the fiber, and we used mechanical stimulation of their hindpaw RFs. Stimuli from a Grass Instruments (Quincy, MA) model 88 stimulator were delivered via bipolar sharp needle electrodes with duration of $0.5-0.75 \mathrm{msec}$ and amplitude of $30-100 \mathrm{~V}$ to activate $\mathrm{C}$-fibers. The main criteria used for physiological characterization and classification of fibers were responses to natural stimulation of their RFs and their conduction velocities, as described previously (Gokin et al., 2001). Conduction velocities (CVs) were calculated by dividing the distance between the stimulating and recording electrodes by the latency of the electrically evoked spike. Units with CVs $<2 \mathrm{~m} / \mathrm{sec}$ were identified as C-fibers (Sanders and Zimmermann, 1986; Handwerker et al., 1991; Leem et al., 1993; Huang et al., 1997). Physiological characterization of C-fibers was based on their responses to various mechanical (light and strong) and thermal (heat and cold) stimulation. They were classified as high-threshold mechanoreceptors (HTMs) if they fired predominantly in response to a strong pinch of the skin with forceps, or von Frey monofilaments (15-52 gm). The thermal responsiveness of mechanically activatable units was determined by applying a heated metal spatula $\left(\sim 52^{\circ} \mathrm{C}\right)$ and a piece of ice (cold stimulation) to their cutaneous RFs. On the basis of both their responses to these stimuli and their CVs, C-units were classified as either (1) 
polymodal (mechano-heat) nociceptors (C-PMNs) or (2) high-threshold mechanoresponsive (HTMr) C-fibers, several of which also responded to thermal stimuli (heat or cold). To confirm that we were recording from the same electrically and physiologically activated unit, a modification of the "blocking" method of Iggo (1958) was used, as described recently by Gokin et al. (2001).

Drug injections were performed in an identical manner to those in the neurobehavioral experiments, except that limb cooling was not used because we showed previously that spike responses are easily obtained with subcutaneous injection of ET-1 without cooling (Gokin et al., 2001). Recording continued in most instances for $40 \mathrm{~min}$ to $2 \mathrm{hr}$ after administration of drugs.

Data analysis. The maximal (peak) number of flinches per $5 \mathrm{~min}$ epoch that occurred during the observation period $(75 \mathrm{~min})$ for each animal was defined as the maximal flinch frequency (MFF) occurring within a 5 min block and was scored independent of the time of occurrence. The MFF, time to reach MFF, total number of flinches occurring within the $75 \mathrm{~min}$ observation period, number of biting or licking events, and total duration of biting or licking behavior were also determined for each animal. Data are reported as means \pm SEM. To establish significant differences between the effects of different ET-1 doses or between injected agents, an unpaired, two-tailed Student's $t$ test was applied (Origin 5.1; Origin Lab, Northampton, MA), with $p<0.05$ considered significant.

For neurophysiological experiments, a response was defined as firing that occurred after completion of the second of two injections and needle withdrawal. The latency of spike response was measured as the time from the end of ET-1 injection to the onset of the first nonelectrically evoked response. The duration of responses was measured from the onset of response until afferent activity returned to baseline. Mean response frequency (MRF) (in impulses per second) was calculated as the number of spikes divided by the duration of the entire ET-1-induced response. Maximum frequency $(\mathrm{MxF})$ was determined, to characterize responses within bursting patterns, as the number of spikes within a brief $(1 \mathrm{sec})$ interval of rapid firing. Duration and MRF were used as quantitative parameters for comparing the magnitudes of responses to different doses of ET-1. All results are presented as means \pm SEM. One-way ANOVA was used to evaluate the significance of the difference of means. Differences were considered statistically significant at $p<0.05$.

\section{RESULTS}

\section{General and behavioral effects of ET-1 injection}

\section{Dermatologic effects}

Similar to results described recently by Gokin et al. (2001), subcutaneous administration of $2(10 \mu \mathrm{l}$ of $200 \mu \mathrm{M}), 4(20 \mu \mathrm{l}$ of $200 \mu \mathrm{M})$, and $6(10 \mu \mathrm{l}$ of $600 \mu \mathrm{M}) \mathrm{nmol}$ of ET-1 into the rat plantar hindpaw induced immediate blanching at the injection site that began 2-5 min after injection and that reached a maximum size of $2.5 \mathrm{~mm}^{2}$. This blanching was followed 5-15 min later by the development of local erythema of the plantar surface and at 20-50 min by diffuse rubor of the hindpaw below the knee that lasted for $60-70 \mathrm{~min}$ before resolving.

\section{ET-1-induced hindpaw flinching}

When ET-1 was injected subcutaneously as a single bolus into the rat plantar paw, ipsilateral hindpaw flinching, a behavioral response that indicates pain behavior in the rat, was observed in $100 \%$ of animals (Davar et al., 1998; Fareed et al., 2000; Gokin et al., 2001). Biting or licking of the hindpaw was also observed in most animals and is reported at the end of Results. Flinching began 5-10 min after observations began, increasing with time until a MFF was reached at $\sim 30-50 \mathrm{~min}$ and resolving to near baseline by $75 \mathrm{~min}$ (Gokin et al., 2001). For single injections of ET-1 (4 nmol, $20 \mu \mathrm{l}$ of $200 \mu \mathrm{M}$ ), the averaged MFF of $40 \pm 4$ flinches $/ 5 \min (n=12)$ occurred at $41 \pm 3$ min after observations began, whereas the averaged total number of flinches was $178 \pm$ 29 over the 75 min observation period.

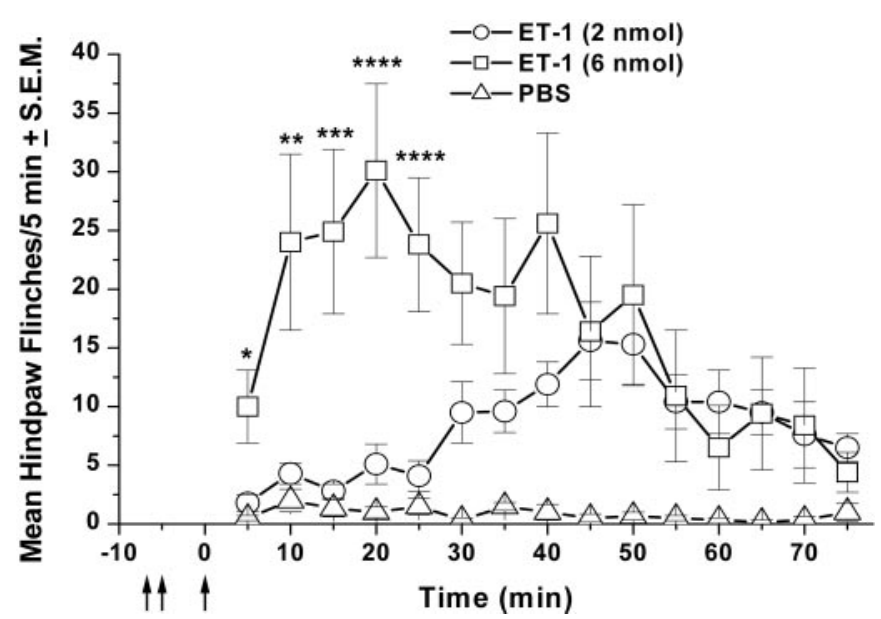

Figure 1. Comparison of the effects of ET-1 injected subcutaneously at concentrations of 200 and $600 \mu \mathrm{M}$ ( 2 and $6 \mathrm{nmol}$ doses, respectively) on the mean number of hindpaw flinches per $5 \mathrm{~min}$ period of observation. The three arrows point to the following: left arrow, injection of PBS; middle arrow, injection of ET-1 or PBS 1.5-2 min later; and right arrow, the beginning of behavioral observations. Significant differences between these doses are present at $5\left({ }^{*} p<0.01\right), 10\left({ }^{* *} p<0.005\right), 15\left({ }^{* * *} p<\right.$ $0.002), 20(* * * * p 0.001)$, and $25(p<0.001)$ min after observations began.

\section{Dose dependence of the effects of ET-1}

Flinching frequency was increased significantly over the 5-25 min period (Fig. 1), as was the averaged MFF (42 \pm 9 flinches $/ 5$ min; $n=8)$ when $6 \mathrm{nmol}$ was injected compared with $2 \mathrm{nmol}(24 \pm 2$ flinches $/ 5 \mathrm{~min} ; n=12 ; p<0.05)$. The mean time to reach $\mathrm{MFF}$ $(22 \pm 4 \mathrm{~min}$ for $6 \mathrm{nmol}$ vs $52 \pm 3 \mathrm{~min}$ for $2 \mathrm{nmol}$ ) was also different for these two doses $(p<0.0001)$, as was the mean total number of flinches $(253 \pm 66$ vs $123 \pm 13$ for 6 vs 2 nmol of ET-1, respectively; $p<0.05)$. A dose of 2 nmol of ET- 1 was therefore selected as reliably submaximal, to further study the effects of agents modulating the $\mathrm{ET}_{\mathrm{B}}$ receptor.

\section{$B Q-788$ enhances ET-1-induced flinching}

To demonstrate a contribution of $\mathrm{ET}_{\mathrm{B}}$ receptors to the paininducing actions of ET-1, we next examined the behavioral consequences of administration of a selective $\mathrm{ET}_{\mathrm{B}}$ receptor antagonist (BQ-788) before and then together with ET-1. As seen in Fig. $2 A$, BQ-788 (3 mM, $60 \mathrm{nmol}$ ) accelerated the development of ET-1-induced hindpaw flinching. Flinching frequency was increased significantly in the presence of BQ-788 at the 15, 20, and 25 min time points (Fig. $2 A$ ), as was the averaged MFF when compared with $2 \mathrm{nmol}$ of ET-1 alone $(p<0.05)$ in 9 of 12 tested rats (Fig. $3 A$ ). Three of 12 rats treated with BQ-788 plus ET-1 showed signs of toxicity (red tears and reduced exploratory behavior) similar to what we observed previously with high doses of ET-1 (Gokin et al., 2001) and, despite evidence of hindpaw rubor, had practically no flinching behavior. These animals were not included in the data analysis.

The averaged MFF also occurred earlier in BQ-788-treated rats $[20 \pm 1(n=9)$ vs $52 \pm 3 \mathrm{~min}(n=12)$ for $2 \mathrm{nmol}$ of ET-1 alone; $p<0.0001]$. Although BQ-788 increased the mean total number of flinches produced by ET- 1 by the same proportion (1.27-fold) as was observed for its effects on MFF, this difference did not reach statistical significance. When administered alone in two subsequent injections of $10 \mu \mathrm{l}, \mathrm{BQ}-788$ did not evoke flinching that was different from PBS for either MFF or total number. 

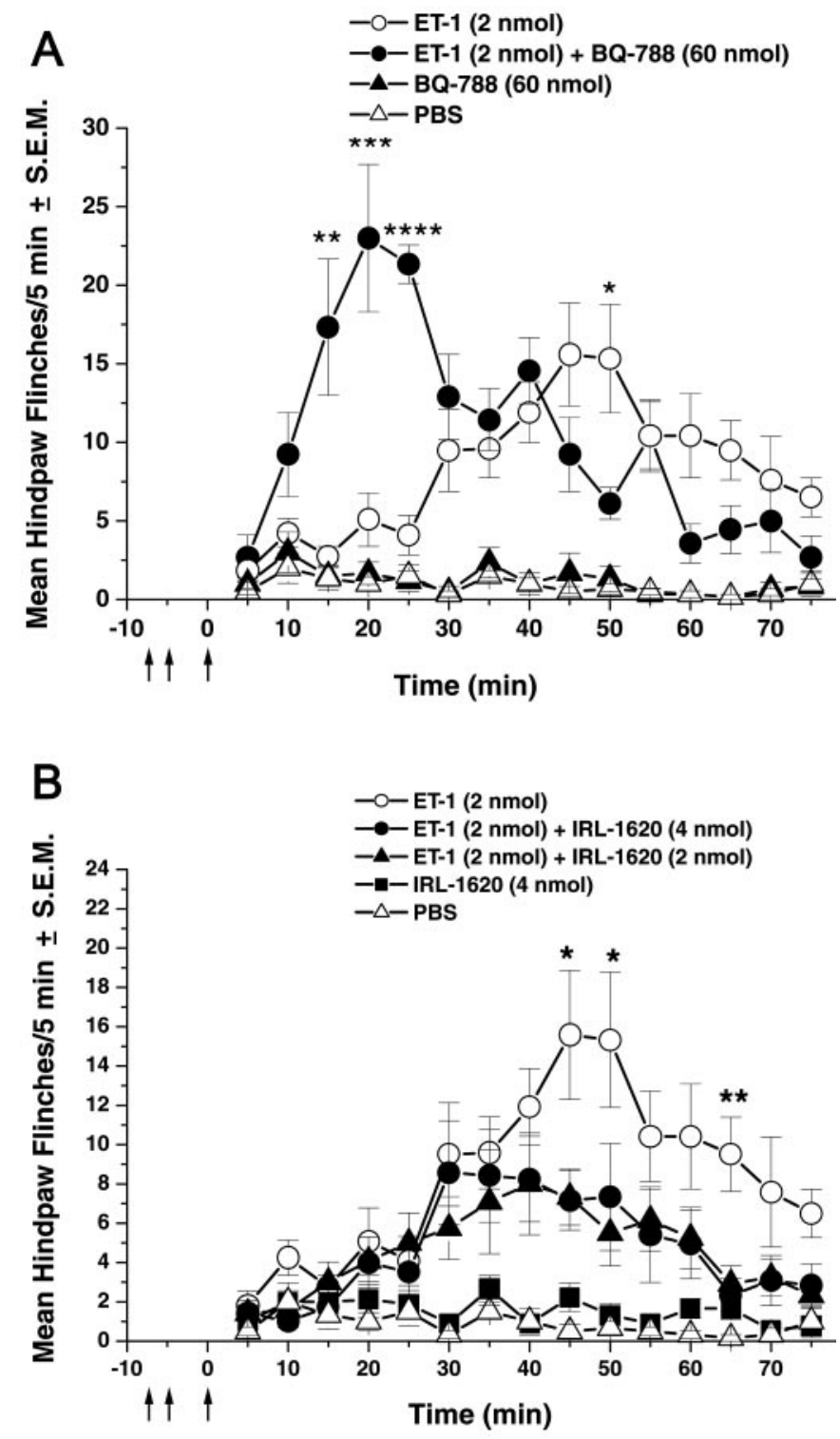

Figure 2. Time course of the effect of ET-1 with BQ-788 (3 mM, total dose of $60 \mathrm{nmol})(A)$ and IRL-1620 (100 or $200 \mu \mathrm{M}$, total dose of 2 or 4 $\mathrm{nmol})(B)$, the latter two injected before and then together with ET-1 (200 $\mu \mathrm{M}$, dose of $2 \mathrm{nmol}$ ), on the mean number of hindpaw flinches per $5 \mathrm{~min}$ period of observation. Effects of BQ-788 (3 mM, $60 \mathrm{nmol})$ alone, IRL$1620(200 \mu \mathrm{M}, 4 \mathrm{nmol})$ alone, and PBS are also presented. The three arrows point to the following: left arrow, injection of BQ-788 or IRL-1620; middle arrow, injection of BQ-788 or IRL-1620 plus ET-1 1.5-2 min later; and right arrow, the beginning of behavioral observations. Differences between ET-1-treated and ET-1 plus BQ-788-treated animals are present at $15\left({ }^{* *} p<0.002\right), 20\left({ }^{* * *} p<0.001\right), 25\left({ }^{* * * *} p<0.0001\right)$, and $50\left({ }^{*} p<\right.$ $0.05)$ min after observations began. Differences between ET-1 and IRL$1620(2 \mathrm{nmol})$ are present at $45\left({ }^{*} p<0.05\right), 50\left({ }^{*} p<0.05\right)$, and $65\left({ }^{* *} p<\right.$ 0.01 ) min after observations began; the $4 \mathrm{nmol}$ dose of IRL-1620 is also significantly different at the $45\left({ }^{*} p<0.05\right)$ and $65\left({ }^{* *} p<0.01\right)$ min time points.

\section{IRL-1620 inhibits ET-1-induced flinching}

To further investigate the role of $\mathrm{ET}_{\mathrm{B}}$ receptors, we next studied the effect of the selective $\mathrm{ET}_{\mathrm{B}}$ receptor agonist IRL-1620 on ET-1-induced flinching. IRL-1620 (200 $\mu \mathrm{M}, 4 \mathrm{nmol})$ decreased the frequency of flinching at later times (significance reached at 45 and $65 \mathrm{~min} ; p<0.05$ ) (Fig. $2 B$ ) and reduced the averaged $\operatorname{MFF}(n=12)$ when compared with ET- 1 alone $(n=12 ; p<0.05)$
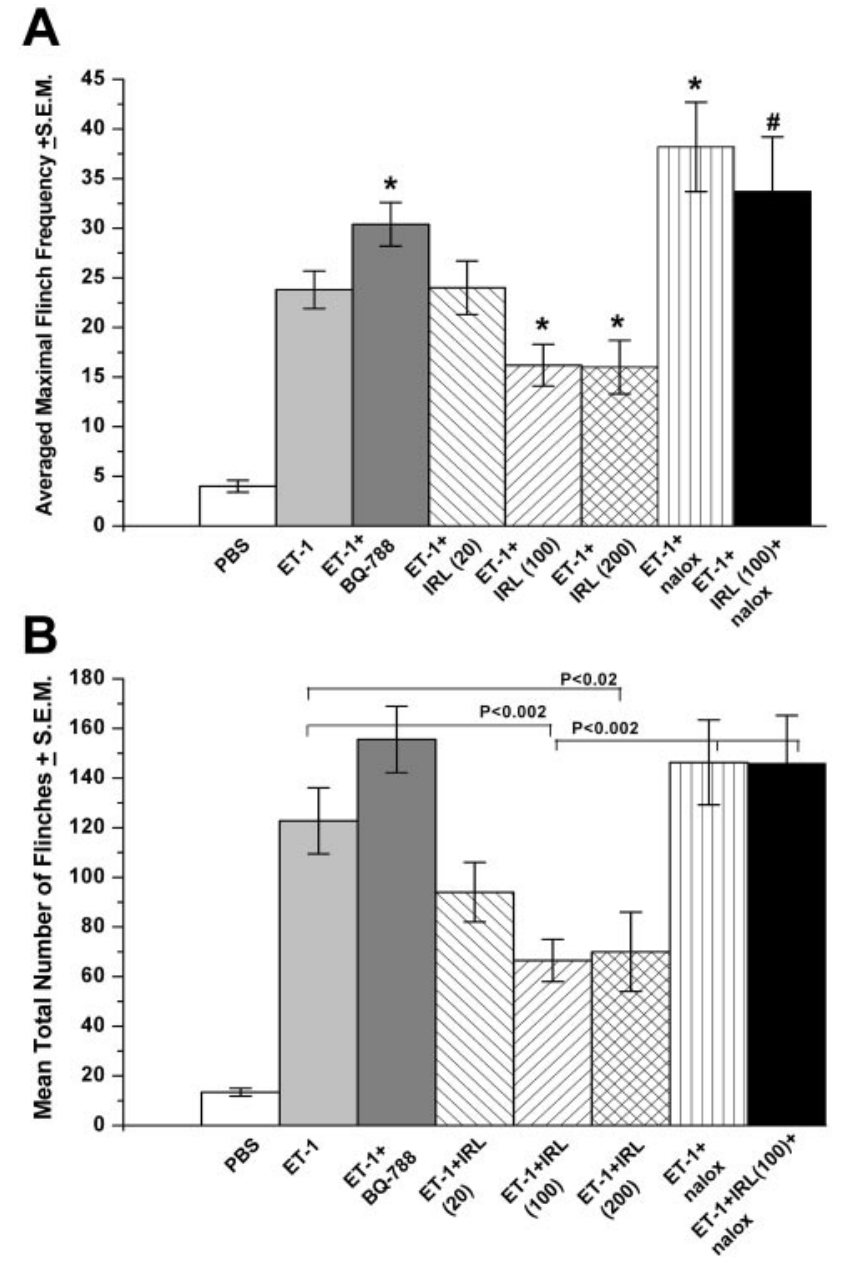

Figure 3. A, Averaged MFF in response to ET-1 (200 $\mu \mathrm{M}, 2 \mathrm{nmol})$ injected together with PBS, BQ-788 (3 mM, $60 \mathrm{nmol})$, IRL-1620 (20, 100, and $200 \mu \mathrm{M}$; total dose of $0.2,2$, or $4 \mathrm{nmol}$, respectively), naloxone $(2.75$ $\mathrm{mm}, 55 \mathrm{nmol})$, or IRL-1620 (100 $\mu \mathrm{M}, 2 \mathrm{nmol})$ plus naloxone. BQ-788 and naloxone enhanced MFF when compared with ET-1 plus PBS $(p<0.05)$, whereas IRL-1620 (100 and $200 \mu \mathrm{M})$ reduced MFF ( $p<0.05) ; 20 \mu \mathrm{M}$ IRL-1620 had no effect on ET-1-induced flinching. Naloxone also fully prevented the inhibitory effects of IRL-1620 on MFF $(\# p<0.05)$. $B$, Mean total number of flinches in response to ET-1 (200 $\mu \mathrm{M}, 2 \mathrm{nmol})$ injected together with PBS, BQ-788 (3 mm, total dose of $60 \mathrm{nmol})$, IRL-1620 (20, 100, and $200 \mu \mathrm{M})$, naloxone $(2.75 \mathrm{mM}, 55 \mathrm{nmol})$, or IRL-1620 $(100 \mu \mathrm{M})$ plus naloxone. IRL-1620 (100 and $200 \mu \mathrm{M})$ inhibits flinching produced by ET-1, whereas naloxone abolished IRL-1620 (100 $\mu \mathrm{M})$ inhibition of flinching.

(Fig. $3 A$ ). The mean total number of flinches was also decreased by IRL-1620 $(p<0.02)$ (Fig. 3B). Although IRL-1620 administered alone in two $10 \mu$ linjections also induced flinching behavior (22 \pm 3 flinches; $n=9$ ) that was slightly higher than observed for PBS alone $(13 \pm 2 ; n=8 ; p<0.05)$, this was not unexpected because some activation of the $\mathrm{ET}_{\mathrm{A}}$ receptor may occur at this concentration of the agonist (Takai et al., 1992).

To help determine whether the actions of IRL-1620 were mediated at a single class of receptors, we next determined the relationship between IRL-1620 dose and flinching behavior. Coadministration of $2 \mathrm{nmol}(20 \mu \mathrm{l}$ total volume, $100 \mu \mathrm{M})$ of IRL1620 with ET-1 had similar effects to 4 nmol of IRL-1620 on ET-1-induced hindpaw flinching (Fig. 2B). The averaged MFF was reduced $(n=12 ; p<0.05)$ (Fig. $3 A)$, as was the mean total number of flinches $(p<0.002)$ (Fig. $3 B)$ when compared with 
ET-1 alone. At the lowest concentration of IRL-1620 (20 $\mu \mathrm{M}$, total dose of $0.4 \mathrm{nmol}$ ) that we used, neither MFF nor total flinches were different from ET-1 alone (Fig. 3). However, MFF did occur earlier $(30.4 \pm 5.8$ vs $51.7 \pm 3.1 \mathrm{~min}$ for ET- 1 alone; $p<$ $0.000005)$, at the same time point observed with higher concentrations of IRL-1620. To reduce any possible actions of IRL-1620 at the $\mathrm{ET}_{\mathrm{A}}$ receptor, while maintaining its inhibitory effects, IRL-1620 was used at the $100 \mu \mathrm{M}$ concentration in subsequent experiments.

\section{Naloxone enhances ET-1-induced flinching}

Opioids are known to have analgesic actions in both the CNS and peripheral nervous system. To examine the potential role of endogenous opioids in the expression of ET-1-induced pain behavior and in $\mathrm{ET}_{\mathrm{B}}$ receptor-mediated antinociception (see below), we next administered the nonselective opioid receptor antagonist naloxone $(2.75 \mathrm{~mm}$, total dose of $55 \mathrm{nmol})$ before and then together with ET-1 ( $2 \mathrm{nmol})$. The averaged MFF was $\sim 50 \%$ higher for naloxone plus ET-1 than for ET-1 alone $(p<0.01)$ (Fig. 3A). Averaged MFF also occurred earlier in naloxonetreated rats $(41 \pm 2$ vs $52 \pm 3$ min for ET-1 alone; $p<0.01)$. However, naloxone did not alter the mean total number of flinches observed (Fig. 3B), nor did naloxone alone induce flinching behavior that was different from PBS $(p>0.05)$.

\section{Naloxone prevents the inhibition of ET-1-induced flinching by IRL-1620}

To more specifically examine the role of opioids in $\mathrm{ET}_{\mathrm{B}}$ receptorinduced antinociception, naloxone was injected together with IRL-1620 (100 $\mu \mathrm{M}, 2 \mathrm{nmol})$ before and then together with ET-1 (2 nmol). The averaged MFF for IRL-1620 plus ET-1 plus naloxone $(n=12)$ was twice that for IRL-1620 plus ET-1 without naloxone $(n=12 ; p<0.05)$, which is evidence that IRL-1620 has no effect in the presence of naloxone (Fig. $3 A$ ). Averaged MFF in this group occurred at $40 \pm 3 \mathrm{~min}$ and was not different from the averaged MFF for ET-1 plus naloxone $(p>0.05)$. The mean total number of flinches evoked by IRL-1620 plus ET-1 plus naloxone was identical to that evoked by ET-1 plus naloxone (Fig. $3 B$ ) and, in both cases, was higher than that evoked by IRL-1620 plus ET-1 $(p<0.002)$. In support of these actions of naloxone at opioid receptors, we have recently observed, in a preliminary manner, that a $\mu$-opioid receptor-selective antagonist (CTOP) can also prevent the actions of IRL-1620 (data not shown).

\section{Biting and licking behavior induced by ET-1 injection}

Biting or licking events were also observed after ET-1 administration in $92 \%(2 \mathrm{nmol})$ and $75 \%(6 \mathrm{nmol})$ of rats compared with $13 \%$ for PBS injections and ranged from 1 to 39 events per rat. Neither the mean number nor the duration of biting or licking events were different between different doses of ET-1 or when ET-1 was compared with BQ-788, IRL-1620, or naloxone administered together with ET-1.

\section{Neurophysiological effects}

To obtain more direct evidence of a naloxone-sensitive inhibitory effect of IRL-1620 on ET-1 induced pain, impulse activity was recorded from 21 physiologically characterized nociceptive C-fibers. Recordings were made before and after subcutaneous injection of ET-1 (200 $\mu \mathrm{M}, 2 \mathrm{nmol} ; n=6)$, IRL-1620 (100 $\mu \mathrm{M}, 1 \mathrm{nmol})$ followed $1-2$ min later by ET-1 $(200 \mu \mathrm{M})$ plus IRL-1620 $(n=12)$, and before and after subcutaneous injection of IRL-1620 (100 $\mu \mathrm{M})$ plus naloxone (2.75 $\mathrm{mm}$ ) followed 1-2 min later by ET-1 (200 $\mu \mathrm{M})$ plus IRL-1620 plus naloxone $(n=3)$ into the cutaneous RFs of these units. The RFs of these units were located on the glabrous hindpaw within territory innervated by the plantar and sural nerves and were 1-2 $\mathrm{mm}$ in size (Fig. 4). The conduction velocities of $\mathrm{C}$-units ranged from 0.63 to 1.1 (mean of $0.86 \pm$ $0.03) \mathrm{m} / \mathrm{sec}$ and were not significantly different between experiments. Most fibers had no ongoing spontaneous activity.

\section{ET-1 induces spike responses in C-nociceptors}

Four of the six units studied here responded only to strong (15-52 gm von Frey hair, numbers 5.18-5.88) mechanical stimulation of their RFs (HTMr units). Noxious pinch gave a maximal response of 11-29 impulses/sec (mean of $17.5 \pm 5.4$ ). The remaining two units also responded to heat (C-PMNs). All six fibers responded to ET-1 $(200 \mu \mathrm{M})$. Five responded in a nearly identical manner, showing the typical bursting discharge pattern (Fig. $4 A$ ) that we described previously (Gokin et al., 2001). The latency (0.315 \pm $0.08 \mathrm{~min}), \mathrm{MRF}(0.318 \pm 0.07$ impulses/sec), and $\mathrm{MxF}$ (4.14 \pm 0.17 impulses/sec) of these six units were also similar to those reported previously by us (Gokin et al., 2001). The duration of responses for these units was $24.13 \pm 3.76 \mathrm{~min}$; most of these units were not observed beyond $40 \mathrm{~min}$ because we never detected a resumption of spiking, under these conditions, once the activity of a unit had returned to baseline.

\section{IRL-1620 inhibits ET-1-induced spike responses}

Twelve C-units were studied. Six were classified as HTMr, two as C-PMNs, two as HTMr that also responded to cold, and two remaining units, one an HTMr that also responded to lowintensity stimuli and the other an HTMr that also responded to low-intensity stimuli and cold. Overall, IRL-1620 (100 $\mu \mathrm{M})$ suppressed ET-1 $(200 \mu \mathrm{M})$ induced spike responses in all units (Table 1). Complete suppression was observed in four of 12 units, whereas late responses of reduced maximal and mean frequency were observed in two of 12 units, and weak responses, showing similar latency to onset to the results with ET-1 alone, were observed in the remaining six units. A typical example of this inhibitory effect of IRL 1620 is seen in Figure $4 B$. Insignificant, or occasionally very short duration ( $\leq 20 \mathrm{sec}$ ), responses were observed in the injection of IRL-1620 alone, which preceded the injection of IRL-1620 plus ET-1 (Fig. 4B).

\section{Naloxone reverses IRL-1620 inhibition of ET-1-induced spike responses}

Three units were recorded (two C-PMNs and one HTMr) while injecting ET-1 and IRL-1620 together with naloxone to their RFs. The typical bursting pattern seen with ET-1 alone was observed in all three units (Fig. 4C). MRF and MxF of responses determined for these three units were not different from those obtained for ET-1 alone but higher than those obtained with ET-1 plus IRL-1620-treated units (Table 1).

\section{DISCUSSION}

These results are evidence that $\mathrm{ET}_{\mathrm{B}}$ receptors are important modulators of $\mathrm{ET}_{\mathrm{A}}$ receptor-mediated pain in cutaneous tissues. ET-1 delivered as a single bolus subcutaneous injection to the rat plantar hindpaw induces hindpaw flinching that is greater and occurs earlier when it is coadministered with a selective $E_{B}$ receptor antagonist, similar to the pattern observed with increas- 

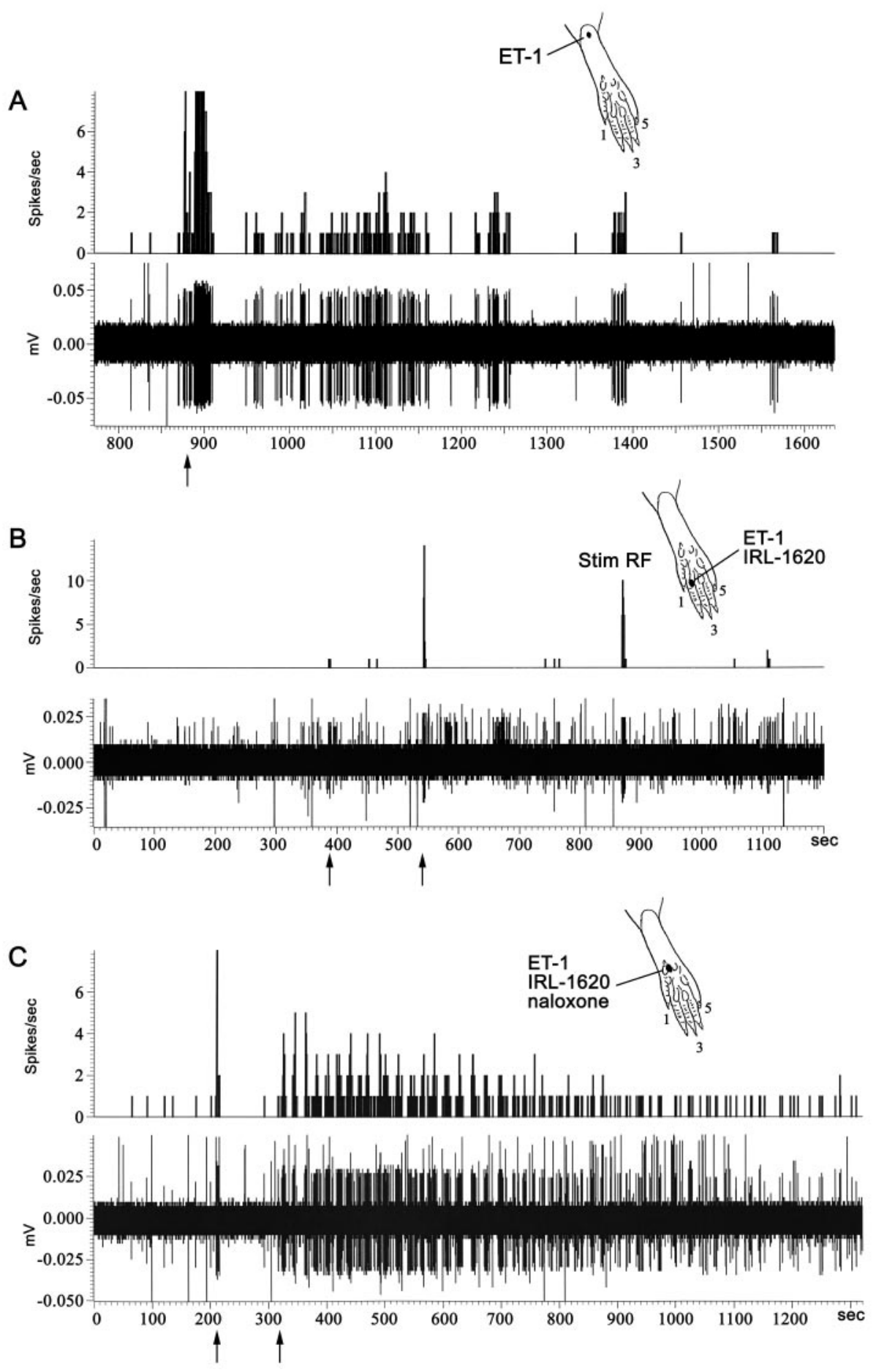

Figure 4. Representative records of spike activity in three C-fibers from three animals after subcutaneous plantar hindpaw injections of ET-1 $(A)$, ET-1 plus IRL-1620 $(B)$, or ET-1 plus IRL 1620 plus naloxone $(C)$, presented as impulse records (bottom traces) and bin histograms (top traces). Insets show the locations of the receptive field of the recorded units on the plantar surface. The volume of each injection was $10 \mu \mathrm{l}$. $A$, Injection of ET-1 $(2 \mathrm{nmol}, 200 \mu \mathrm{M}$, at the upward arrow) rapidly induces the characteristic "bursting" pattern of a long-lasting spike discharge in a C-PMN fiber. $B$, The same dose of ET-1, in the presence of IRL-1620 (2 nmol total dose, $100 \mu \mathrm{M}$ ), fails to provoke a spike response in an HTMr fiber that lasts beyond the injection discharge (upward arrows). Noxious pinch (Stim $R F$ ) performed 5.5 min after injections demonstrates continued mechanoresponsiveness of the $\mathrm{RF}$ of the unit. Impulse activity that is recorded as primarily upward spikes belongs to an $\mathrm{A} \delta$ fiber whose $\mathrm{RF}$ overlapped this $\mathrm{C}$-unit. The spikes of the C-unit are almost symmetrically biphasic, and its response is summarized in the accompanying bin histogram. $C$, Injection of naloxone $(2.75 \mathrm{mM})$ together with ET-1 $(200 \mu \mathrm{M})$ and IRL-1620 $(100 \mu \mathrm{M})$ induces a spike response in a C-PMN unit with rapid onset and bursting pattern that lasts for $>17 \mathrm{~min}$. The arrow in $A$ indicates the time of ET-1 injection, and those in $B$ and $C$ show the first (IRL-1620 or IRL-1620 plus naloxone) and the second (ET-1 plus IRL-1620 or ET-1 plus IRL-1620 plus naloxone) injections, respectively. ing ET-1 dose. Conversely, coadministration of a selective $\mathrm{ET}_{\mathrm{B}}$ receptor agonist reduces hindpaw flinching and inhibits ET-1induced spike responses in nociceptors, both of which are prevented by local injection of the nonselective opioid receptor antagonist naloxone.

Although relatively high concentrations of ET-1 (and BQ-788 and IRL-1620) were used in these experiments, the local concentrations of these agents at the receptor sites are unknown, and their diffusion to the receptors is limited by closely opposed dermal and epidermal cells, the vascular flow that rapidly removes many small molecules, and by the actions of many degradative enzymes. Analogously high concentrations of relatively hydrophobic compounds, such as local anesthetics (e.g., 30-50× the $\mathrm{IC}_{50}$ on isolated neurons) are often needed to obtain in vivo efficacy from subcutaneous delivery (Khodorova and Strichartz, 2000). The endogenous concentration of ET-1 released by cutaneous tissue injury might indeed be low (Hara et al., 1995; Tsuboi et al., 1995) yet sufficient to induce flinching behavior in rats (Gokin et al., 2001). Increasing the concentration of ET-1 increased flinching, which peaked earlier. This enhanced effect may be the result of increased actions at the $\mathrm{ET}_{\mathrm{A}}$ receptor as a consequence of increased ET-1 dose (Fareed et al., 2000). How- 


\begin{tabular}{|c|c|c|c|c|c|}
\hline Drug & $\begin{array}{l}\text { Number } \\
\text { of units }\end{array}$ & $\begin{array}{l}\text { Mean response } \\
\text { frequency } \\
\text { (impulses/sec) }\end{array}$ & $\begin{array}{l}\text { Maximum re- } \\
\text { sponse frequency } \\
\text { (impulses/sec) }\end{array}$ & $\begin{array}{l}\text { Mean duration } \\
\text { of response } \\
\text { (min) }\end{array}$ & $\begin{array}{l}\text { Mean latency } \\
\text { of response } \\
\text { (min) }\end{array}$ \\
\hline ET-1 alone & 6 & $0.32 \pm 0.07$ & $4.17 \pm 0.17$ & $24.13 \pm 3.76$ & $0.32 \pm 0.08$ \\
\hline ET-1 plus IRL-1620 & 12 & $0.08 \pm 0.02^{*}$ & $1.5 \pm 0.4^{*}$ & $\mathrm{NA}^{a}$ & $\mathrm{NA}^{a}$ \\
\hline ET-1 plus IRL-1620 plus naloxone & 3 & $0.21 \pm 0.10$ & $3.66 \pm 0.33$ & $25.5 \pm 6.7$ & $0.28 \pm 0.14$ \\
\hline
\end{tabular}

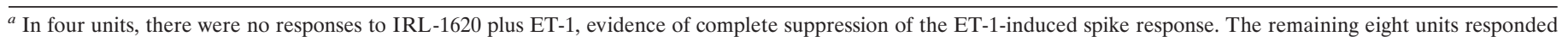

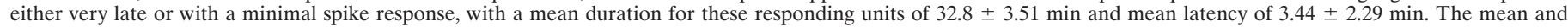
maximum response frequencies reported are for all 12 units treated with ET-1 plus IRL-1620. NA, Not applicable.

${ }^{*} p<0.001$, Fisher's PLSD, when compared with ET-1 alone.

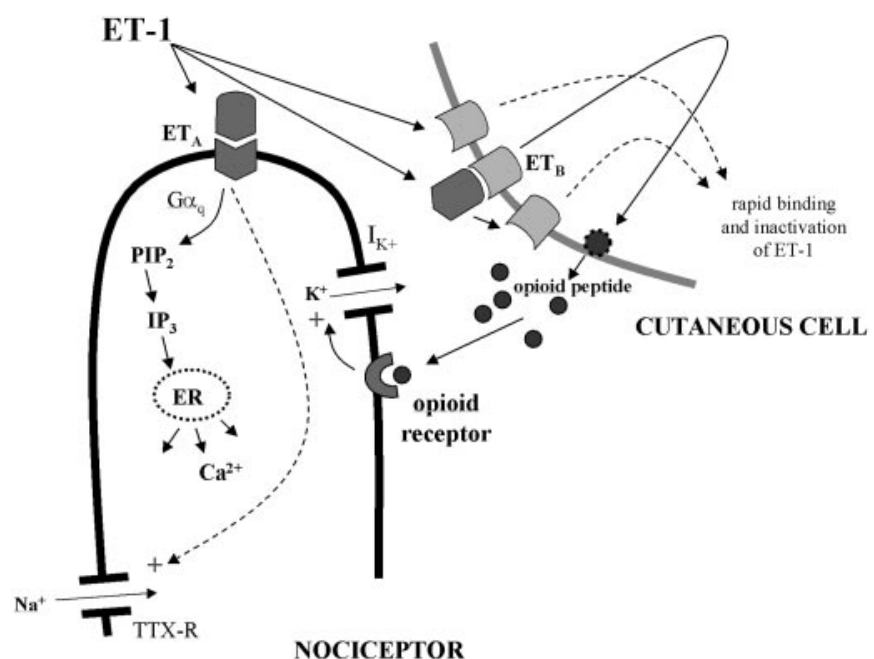

Figure 5. Proposed model for the mechanisms of $\mathrm{ET}_{\mathrm{B}}$ receptor-induced inhibition of the effects of ET-1. Activation of $\mathrm{ET}_{\mathrm{A}}$ receptors on nociceptors by ET-1 (exogenous or locally released) induces release of calcium from intracellular stores (Zhou et al., 2001) and enhancements of tetrodotoxin-resistant (TTX-R) sodium currents (Chen et al., 2000; Zhou et al., 2002), which may contribute to ET-1-induced spike responses and pain (Gokin et al., 2001). In contrast, binding of ET-1 to $\mathrm{ET}_{\mathrm{B}}$ receptors on cutaneous cells (e.g., keratinocytes) leads to both the rapid internalization and inactivation of bound ET-1 (Bremnes et al., 2000; Paasche et al., 2001) and to the release of opioid peptides, which activate opioid receptors on nociceptors (Stein et al., 1990b). These opioid receptors are in turn likely coupled to ion channels that could hyperpolarize the nociceptor (e.g., $\left.I_{K}^{+}\right)$, thereby suppressing $\mathrm{ET}_{\mathrm{A}}$ receptor-induced nociceptive firing.

ever, increased availability of ET-1 that may occur secondary to its reduced internalization and inactivation by the $\mathrm{ET}_{\mathrm{B}}$ receptor, a process described in heterologous expression systems (Bremnes et al., 2000; Paasche et al., 2001), might also contribute to this result (Fig. 5). The earlier onset of flinching is also consistent with reduced actions at the $\mathrm{ET}_{\mathrm{B}}$ receptor, as we observed with $\mathrm{ET}_{\mathrm{B}}$ receptor blockade, which may lead to enhanced and accelerated actions of ET-1 at the $\mathrm{ET}_{\mathrm{A}}$ receptor (Rubanyi and Polokoff, 1994).

Consistent with the proposed role for $\mathrm{ET}_{\mathrm{B}}$ receptors in the modulation of the $\mathrm{ET}_{\mathrm{A}}$ receptor-mediated response, blockade of the $\mathrm{ET}_{\mathrm{B}}$ receptor also increases flinching and accelerates its onset. This suggests the possibility that $\mathrm{ET}_{\mathrm{B}}$ receptor activation inhibits and delays the effects of $\mathrm{ET}_{\mathrm{A}}$ receptor activation. The substantially reduced $(50 \%)$ flinching observed with an $\mathrm{ET}_{\mathrm{B}}$ receptor agonist further supports the idea that $\mathrm{ET}_{\mathrm{B}}$ receptors can suppress $\mathrm{ET}_{\mathrm{A}}$ receptor-mediated pain in cutaneous tissues. Low- ering the dose of IRL-1620 by a factor of 10 eliminated its inhibition of flinching behavior, pointing to a moderately steep dose-response relationship that is consistent with actions at a single class of receptors.

The inhibitory effect of $\mathrm{ET}_{\mathrm{B}}$ receptor activation is unlikely to be through sensory fibers themselves, whereon $\mathrm{ET}_{\mathrm{B}}$ receptors have not been detected (Pomonis et al., 2001), and instead is more likely the result of an indirect action mediated by another cell that leads to the suppression of spike activity in nociceptors. The prevention of IRL-1620-induced inhibition of flinching by locally injected naloxone supports this hypothesis and suggests the possibility that $\mathrm{ET}_{\mathrm{B}}$ receptor activation on adjacent cutaneous cells leads to the release of an endogenous opioid peptide. The source of this peptide could either be a supportive glial cell [e.g., a non-ensheathing Schwann cell (Pomonis et al., 2001)] found adjacent to cutaneous sensory axons or a resident cutaneous cell (Tada et al., 1998). Among cutaneous cells, keratinocytes are closely associated with sensory axons (Haberberger and Bodenbenner, 2000) and modulate the activity of cutaneous nociceptors (Lewin and Mendell, 1993). They also possess ET $_{\mathrm{B}}$ receptors and express and secrete opioid peptides in a regulated manner (Wintzen et al., 1996, 2000; Zanello et al., 1999), making them reasonable candidates to mediate the $\mathrm{ET}_{\mathrm{B}}$ receptor effects we observed here. Other cutaneous cells that possess $\mathrm{ET}_{\mathrm{B}}$ receptors and express pro-opiomelanocortin, such as fibroblasts, might also be candidates for a cellular source of $\mathrm{ET}_{\mathrm{B}}$ receptor-induced opioid secretion in plantar hindpaw (Teofoli et al., 1999; Shraga-Levine and Sokolovsky, 2000). In addition, inflammatory cells such as lymphocytes recruited to sites of tissue injury could release opioid peptides (Cabot et al., 1997) and might respond to ET-1, but the rapid inhibitory effects we observed here do not support this slower process that is dependent on cellular migration.

Impulse activity in nociceptors after the subcutaneous injection of ET-1, identical in pattern and intensity to what was reported previously (Gokin et al., 2001), was inhibited by coinjection of the $\mathrm{ET}_{\mathrm{B}}$ receptor agonist. Spike responses in identified $\mathrm{C}$-nociceptors were completely abolished in several units, whereas the response latency and the duration of response was prolonged in the remaining units. These results provide a mechanism for the inhibitory actions of $\mathrm{ET}_{\mathrm{B}}$ receptor activation on ET-1-induced pain behavior. More importantly, the prevention of this effect by locally administered naloxone supports the possibility of an opioid receptormediated action of IRL-1620 and helps validate our model of $\mathrm{ET}_{\mathrm{B}}$ receptor-induced modulation of $\mathrm{ET}_{\mathrm{A}}$ receptor actions on nociceptors in skin (Fig. 5). Incomplete suppression of spike responses in some units might be the result of partial actions of 
IRL-1620 at the $\mathrm{ET}_{\mathrm{A}}$ receptor, as described above, or secondary to competition with ET-1 for $\mathrm{ET}_{\mathrm{B}}$ receptor binding sites, leading to increased actions at $\mathrm{ET}_{\mathrm{A}}$ receptors. The prolonged latency with low-level firing in responding units is consistent with the selective actions of this potent $\mathrm{ET}_{\mathrm{B}}$ receptor agonist, which would be expected to delay the onset of $\mathrm{ET}_{\mathrm{A}}$ receptormediated firing.

These results suggest a dual level of control over the painrelated actions of ET-1 in cutaneous tissues, much like its divergent actions of vasoconstriction and vasodilatation in vascular tissue, respectively, mediated by $\mathrm{ET}_{\mathrm{A}}$ and $\mathrm{ET}_{\mathrm{B}}$ receptors found on different vascular cells (Rubanyi and Polokoff, 1994). Thus, in cutaneous tissues, $\mathrm{ET}_{\mathrm{A}}$ receptors on nociceptors can directly activate pain responses, whereas $\mathrm{ET}_{\mathrm{B}}$ receptors on supportive cells inhibit these effects of ET-1 in a naloxonesensitive manner. The source and type of opioid peptide that mediates this effect is unknown but likely originates locally from cutaneous or supportive cells. Based on these results, we surmise that $\mathrm{ET}_{\mathrm{B}}$ receptor activation in cutaneous tissues leads to the local release of an endogenous opioid peptide that hyperpolarizes nociceptors, in the face of $\mathrm{ET}_{\mathrm{A}}$ receptordependent excitation, thereby suppressing impulse generation and inhibiting the effects of ET- 1 .

\section{REFERENCES}

Ahn GY, Butt KI, Jindo T, Yaguchi H, Tsuboi R, Ogawa H (1998) The expression of endothelin-1 and its binding sites in mouse skin increased after ultraviolet B irradiation or local injection of tumor necrosis factor alpha. J Dermatol 25:78-84.

Bremnes T, Paasche JD, Mehlum A, Sandberg C, Bremnes B, Attramadal H (2000) Regulation and intracellular trafficking pathways of the endothelin receptors. J Biol Chem 275:17596-17604.

Cabot PJ, Carter L, Gaiddon C, Zhang Q, Schafer M, Loeffler JP, Stein C (1997) Immune cell-derived beta-endorphin. Production, release, and control of inflammatory pain in rats. J Clin Invest 100:142-148.

Carducci MA, Nelson JB, Bowling MK, Rogers T, Eisenberger MA, Sinibaldi V, Donehower R, Leahy TL, Carr RA, Isaacson JD, Janus TJ, Andre A, Hosmane BS, Padley RJ (2002) Atrasentan, an endothelin receptor antagonist for refractory adenocarcinomas: safety and pharmacokinetics. J Clin Oncol 20:2171-2180.

Chen X, Zhou Z, Strichartz GR, Davar G (2000) Endothelin-1mediated inhibition of inward barium current in sensory neuronal hybrid (F-11) cells. Soc Neurosci Abstr 26:1694.

Dahlof B, Gustafsson D, Hedner T, Jern S, Hannsson L (1990) Regional hemodynamic effects of endothelin-1 in rat and man: unexpected adverse effects. J Hypertens 8:811-818.

Davar G, Hans G, Fareed MU, Sinnott C, Strichartz G (1998) Behavioral signs of acute pain produced by application of endothelin-1 to rat sciatic nerve. NeuroReport 9:2279-2283.

De-Melo JD, Tonussi CR, D’Orleans-Juste P, Rae GA (1998) Articular nociception induced by endothelin-1, carrageenan and LPS in naive and previously inflamed knee-joints in the rat: inhibition by endothelin receptor antagonists. Pain 77:261-269.

Eisenberg E, Vos BP, Strassman AM (1996) The peripheral antinociceptive effect of morphine in a rat model of facial pain. Neuroscience 72:519-525.

Fareed MU, Hans G, Atanda A, Strichartz G, Davar G (2000) Pharmacological characterization of acute pain behavior produced by application of endothelin-1 to rat sciatic nerve. J Pain 1:46-53.

Ferreira SH, Romitelli M, de Nucci G (1989) Endothelin-1 participation in overt and inflammatory pain. J Cardiovasc Pharmacol 13 [Suppl 5]:S220-S222.

Gokin AP, Fareed MU, Pan H-L, Hans G, Strichartz GR, Davar G (2001) Local injection of endothelin-1 produces pain-like behavior and excitation of nociceptors in rats. J Neurosci 21:5358-5366.

Graido-Gonzalez E, Doherty JC, Bergreen EW, Organ G, Telfer M, McMillen MA (1998) Plasma endothelin-1, cytokine, and prostaglandin E2 levels in sickle cell disease and acute vaso-occlusive sickle crisis. Blood 92:2551-2555.

Griswold DE, Douglas SA, Martin LD, Davis TG, Davis L, Ao Z, Luttmann MA, Pullen M, Nambi P, Hay DW, Ohlstein EH (1999) Endothelin B receptor modulates inflammatory pain and cutaneous inflammation. Mol Pharmacol 56:807-812.

Haberberger RV, Bodenbenner M (2000) Immunohistochemical local- ization of muscarinic receptors (M2) in the rat skin. Cell Tissue Res 300:389-396.

Hammerman SI, Kourembanas S, Conca TJ, Tucci M, Brauer M, Farber HW (1997) Endothelin-1 production during the acute chest syndrome in sickle cell disease. Am J Respir Crit Care Med 156:280-285.

Handwerker HO, Kilo S, Reeh PW (1991) Unresponsive afferent nerve fibres in the sural nerve of the rat. J Physiol (Lond) 435:229-242.

Hara M, Yaar M, Gilchrest BA (1995) Endothelin-1 of keratinocyte origin is a mediator of melanocyte dendricity. J Invest Dermatol 105:744-748.

Hickey KA, Rubanyi GM, Paul RJ, Highsmith RF (1985) Characterization of a coronary vasoconstrictor produced by cultured endothelial cells. Am J Physiol 248:C550-C556.

Huang JH, Thalhammer JG, Raymond SA, Strichartz GR (1997) Susceptibility to lidocaine of impulses in different somatosensory afferent fibers of rat sciatic nerve. J Pharmacol Exp Ther 282:802-811.

Iggo A (1958) Electrophysiological identification of single nerve fibers with particular relevance to the slowest-conducting vagal afferent fibers in the cat. J Physiol (Lond) 142:110-126.

Ishikawa K, Fukami T, Nagase T, Fujita K, Hayama T, Niiyama K, Mase T, Ihara M, Yano M (1992) Cyclic pentapeptide endothelin antagonists with high ETA selectivity. Potency- and solubility-enhancing modifications. J Med Chem 35:2139-2142.

Jarvis MF, Wessale JL, Zhu CZ, Lynch JJ, Dayton BD, Calzadilla SV, Padley RJ, Opgenorth TJ, Kowaluk EA (2000) ABT-627, an endothelin ET(A) receptor-selective antagonist, attenuates tactile allodynia in a diabetic rat model of neuropathic pain Eur J Pharmacol 388:29-35.

Khodorova AB, Strichartz GR (2000) The addition of dilute epinephrine produces equieffectiveness of bupivacaine enantiomers for cutaneous analgesia in the rat. Anesth Analg 91:410-416.

Leem JW, Willis WD, Chung JM (1993) Cutaneous sensory receptors in the rat foot. J Neurophysiol 69:1684-1699.

Lewin GR, Mendell LM (1993) Nerve growth factor and nociception. Trends Neurosci 16:353-359.

Paasche JD, Attramadal T, Sandberg C, Johansen HK, Attramadal H (2001) Mechanisms of endothelin receptor subtype-specific targeting to distinct intracellular trafficking pathways. J Biol Chem 276:34041-34050

Piovezan AP, D'Orleans-Juste P, Tonussi CR, Rae GA (1997) Endothelins potentiate formalin-induced nociception and paw edema in mice. Can J Physiol Pharmacol 75:596-600.

Piovezan AP, D'Orleans-Juste P, Tonussi CR, Rae GA (1998) Effects of endothelin-1 on capsaicin-induced nociception in mice. Eur J Pharmacol 351:15-22.

Piovezan AP, D'Orleans-Juste P, Souza GE, Rae GA (2000) Endothelin-1-induced ET(A) receptor-mediated nociception, hyperalgesia and oedema in the mouse hind-paw: modulation by simultaneous ET(B) receptor activation. Br J Pharmacol 129:961-968.

Pomonis JD, Rogers SD, Peters CM, Ghilardi JR, Mantyh PW (2001) Expression and localization of endothelin receptors: implications for the involvement of peripheral glia in nociception $J$ Neurosci 21:999-1006.

Raffa R, Schupsky J, Jacoby H (1996a) Endothelin-induced nociception in mice: mediation by $\mathrm{ET}_{\mathrm{A}}$ and $\mathrm{ET}_{\mathrm{B}}$ receptors. $\mathrm{J}$ Pharmacol Exp Ther 276:647-651.

Raffa R, Schupsky J, Lee D, Jacoby H (1996b) Characterization of endothelin-induced nociception in mice: evidence for a mechanistically distinct analgesic model. J Pharmacol Exp Ther 278:1-7.

Rubanyi GM, Polokoff MA (1994) Endothelins: molecular biology, biochemistry, pharmacology, physiology, and pathophysiology. Pharmacol Rev 48:325-415.

Sanders KH, Zimmermann M (1986) Mechanoreceptors in rat glabrous skin: redevelopment of function after nerve crush. J Neurophysiol 55:644-659.

Shraga-Levine Z, Sokolovsky M (2000) Functional coupling of G proteins to endothelin receptors is ligand and receptor subtype specific Cell Mol Neurobiol 20:305-317.

Stein C, Gramsch C, Herz A (1990a) Intrinsic mechanisms of antinociception in inflammation: local opioid receptors and beta-endorphin. J Neurosci 10:1292-1298.

Stein C, Hassan AH, Przewlocki R, Gramsch C, Peter K, Herz A (1990b) Opioids from immunocytes interact with receptors on sensory nerves to inhibit nociception in inflammation. Proc Natl Acad Sci USA 87:5935-5939.

Tada A, Suzuki I, Im S, Davis MB, Cornelius J, Babcock G, Nordlund JJ, Abdel-Malek ZA (1998) Endothelin-1 is a paracrine growth factor that modulates melanogenesis of human melanocytes and participates in their responses to ultraviolet radiation. Cell Growth Differ 9:575-584.

Takai M, Umemura I, Yamasaki K, Watakabe T, Fujitani Y, Oda K, Urade Y, Inui T, Yamamura T, Okada T (1992) A potent and specific agonist, Suc-[Glu9, Ala11, 15]-endothelin-1(8-21), IRL 1620, for the ETB receptor. Biochem Biophys Res Commun 184:953-959.

Teofoli P, Frezzolini A, Puddu P, De Pita O, Mauviel A, Lotti T (1999) 
The role of proopiomelanocortin-derived peptides in skin fibroblast and mast cell functions. Ann NY Acad Sci 885:268-276.

Tsuboi R, Sato C, Oshita Y, Hama H, Sakurai T, Goto K, Ogawa H (1995) Ultraviolet B irradiation increases endothelin-1 and endothelin receptor expression in cultured human keratinocytes. FEBS Lett 371: $188-190$.

Webber KM, Pennefather JN, Head GA, van den Buuse M (1998) Endothelin induces dopamine release from rat striatum via endothelin-B receptors. Neuroscience 86:1173-1180.

Wintzen M, Yaar M, Burbach JP, Gilchrest BA (1996) Proopiomelanocortin gene product regulation in keratinocytes. J Invest Dermatol 106:673-678

Wintzen M, Zanello SB, Holick MF, Wiegant VM, Burbach JP, Vermeer BJ (2000) Condition-dependent presence of beta-lipotropin-like peptide in human keratinocytes. Peptides 21:691-697.
Yanagisawa M, Kurihara H, Kimura S, Tomobe Y, Kobayashi M, Mitsui Y, Yazaki Y, Goto K, Masaki T (1988) A novel potent vasoconstrictor peptide produced by vascular endothelial cells. Nature 332:411-415.

Zanello SB, Jackson DM, Holick MF (1999) An immunocytochemical approach to the study of beta-endorphin production in human keratinocytes using confocal microscopy. Ann NY Acad Sci 885:85-99.

Zhou Q-L, Strichartz G, Davar G (2001) Endothelin-1 activates ET receptors to increase intracellular calcium in model nociceptors. NeuroReport 12:3853-3857.

Zhou Z, Davar G, Strichartz G (2002) Endothelin-A receptor dependent enhanced activation gating of tetrodotoxin-resistant sodium currents in rat sensory neurons: a possible mechanism of ET-1 induced pain. J Neurosci, in press.

Zimmermann M (1983) Ethical guidelines for investigations of experimental pain in conscious animals. Pain 16:109-110. 